\title{
The myth of the big bang
}

\section{Lawrence Rogers}

\section{Abstract}

Defining 'myth' is fraught with philosophical, political and linguistic challenges. This essay endeavours to explore the epistemological assumptions and characteristics that make up myth through comparing the modern aetiology of 'the big bang' and Hesiod's Theogony. A survey has been conducted in conjunction with this essay to gain an understanding of the ways in which people today think about the big bang. Ultimately, the essay will conclude that Theogony and the big bang have many characteristics in common, and can arguably both be labelled as 'myth'. Importantly, the epistemic background of the two aetiologies - the ways in which people understand myth - are often shared, as people use belief systems to comprehend these concepts. To explore the question this essay will first frame the established theoretical framework of 'myth'. Amongst this discussion, a suitable definition by Lauri Honko will be chosen to further analyse and compare Theogony and the big bang. Implications of the analysis will then be given in relation to the definition of myth, focusing on the epistemic assumptions the word and concept holds. 


\section{Framing 'myth'}

There are many competing definitions and theories of myth. Lincoln rightly states that there is no "clear and concise definition of "myth". ${ }^{1}$ Mythologists, folklorists, anthropologists and psychologists all have varying opinions on what and what does not count as myth. ${ }^{2}$ Without going into too much detail, scholars usually differentiate their definitions of myth based on different aspects of myth. For example, Gaster highlights the interconnectedness of ritual and myth as its defining aspect. ${ }^{3}$ Malinowski identifies the importance of a function in society for myth. ${ }^{4}$ Kirk takes a generalist approach and goes as far as to say that 'traditional oral tale' is the only safe broad definition for what a myth is. ${ }^{5}$

A broad yet detailed definition given by Honko will be used throughout this essay. His definition identifies four criteria that make up myth: form, content, function and context. ${ }^{6}$ Under form, a myth is a narrative that can be verbal and may be supplemented by symbols, allusions and drama. A myth's content is cosmogonic 'information about decisive, creative events in the beginning of time'. The function of a myth is as an example or a model for behaviour and are integrated into a coherent view of the world. Finally, the context of myth is ritual, a pattern of behaviour sanctioned by usage. ${ }^{8}$ Honko's definition is most useful because it encompasses a large range of characteristics of myth, which accounts for stories we may call myths that do not fit all of

1 B. Lincoln. 1999. Theorizing Myth: Narrative, Ideology, and Scholarship. Chicago: University of Chicago Press, p. xi.

2 William Bascom. 1984. 'The Forms of Folklore: Prose Narratives.' In Sacred Narrative, ed. Alan Dundes. Los Angeles: University of California Press; Jan De Vries. 1984. 'Theories Concerning 'Nature Myths.' In Sacred Narrative, ed. Alan Dundes. Los Angeles: University of California Press; Lauri Honko. 1984. 'The Problem of Defining Myth.' In Sacred Narrative, ed. Alan Dundes. Los Angeles: University of California Press; G.S. Kirk. 1984. 'On Defining Myths.' In Sacred Narrative, ed. Alan Dundes. Los Angeles: University of California Press; Raffaele Pettazoni. 1984. 'The Truth of Myth.' In Sacred Narrative, ed. Alan Dundes. Los Angeles: University of California Press; Theodor H. Gaster. 1984. 'Myth and Story.' In Sacred Narrative, ed. Alan Dundes. Los Angeles: University of California Press.

3 Gaster, 'Myth and Story', pp. 112-13.

4 Bronislaw Malinowski. 1984. 'The Role of Myth in Life.' In Sacred Narrative, ed. Alan Dundes. Los Angeles: University of California Press, p. 197.

5 Kirk, 'On Defining Myths', p. 57.

6 Honko, 'The Problem of Defining Myth, pp. 49-51.

7 Ibid., p. 50.

8 Ibid., p. 51. 
the four criteria perfectly. This definition is better than Kirk's from above, as a 'traditional oral tale' does not give indication of the facets that make up 'myth'. Both Hesiod's Theogony and the 'big bang' will be compared and contrasted under the criteria established by Honko.

\section{Analysis of the two aetiologies}

Hesiod's Theogony fits easily within the four criteria. Its form is a clear narrative of how the universe began. ${ }^{9}$ Its stories are associated with images such as depictions of the Greek gods and their defining characteristics. Additionally, Theogony was in the form of a hexameter epic poem and was often recited to ancient audiences. These aspects all fit the content criteria. Theogony's content also fits the definition as it tells the story of the beginning of the world - 'first of all Chasm came to be, and then broad breasted Earth' ${ }^{10}$ - along with the rest of the world's features and how Zeus came to rule the world order. In this way, Hesiod's story provides a cosmogenic depiction of the world. Theogony served an ontological function in Greek society. It established a static world order that society believed in, as Pan-Hellenic gods became codified. Its cosmogenic nature lent the function of the Greek polytheist faith system. ${ }^{11}$ The final criteria - context - is also satisfied by Theogony. Theogony introduced and legitimised the ritual of sacrifice: 'human beings upon the earth burn white bones upon smoking alters for the immortals. This ritual was used to bring the mythic past into the present and served to maintain the relationship between the gods and humankind.

The big bang is difficult to analyse due to its scientific nature. We aim to discuss the understanding of the big bang in the everyday person, rather than the understanding of an educated scientist. To isolate the concept to the 'layperson', a survey has been conducted that has sampled 87 people of all ages in Australia, of which 47 (54 per cent) could not explain any evidence of the big bang. It must also be understood that a large number of respondents will be highly educated, as the survey was primarily posted on a university social media group page. In relation to form of the big bang, it can be classified as

9 L. Maurizio. 2015. Classical Mythology in Context. USA: Oxford University Press.

10 Hesiod. 2006. Theogony. Works and Days. Testimonia, vol. 57, 503. Edited and translated by Glenn W. Most. Cambridge, Mass: Harvard University Press, pp. 116-7.

11 Hesiod, Theogony, p. xx. 
a narrative. Over 70 per cent of respondents agreed that they could explain the big bang as a story or narrative. Additionally, respondents agreed that depictions of the big bang in media are dramatised, and often associate the concept of the big bang with images given by the media. The form criterion above is inclusive of images, and performative (audio-visual) formats, therefore the big bang fits it without too much difficulty. The big bang's content is cosmogenic, with 87 per cent of participants trusting that the big bang theory is the best account of the beginning of the universe. This complies with the content criteria.

The function of the big bang is unclear, however, there is room for exploration. The big bang certainly provides an integrated view of the world. As a cosmogony, it provides information for people to understand natural phenomena, and it can be argued that it can be placed into a holistic confidence in the scientific field - of which 86 per cent of participants trust to provide the best explanations for natural phenomena. Importantly, of those who could not explain any evidence for the big bang (54 per cent of all respondents), an overwhelming majority ( 40 of 47 ) still trust the scientific field to provide the best explanations of natural phenomenon. This leads to the notion that the epistemic system a layperson uses to understand the big bang is not grounded in reason, but instead faith or belief. The big bang then becomes a narrative with which a person can understand their everyday lives, where we came from, why we are here and how 'everything' begun. The layperson doesn't need or often doesn't have the desire to understand the formal reasoning behind the theory, and therefore it has a simpler explanatory function that is integrated into a larger worldview. The big bang can, therefore, satisfy the function criteria of myth.

The big bang does not fully satisfy the final criteria in relation to context. The big bang does not justify or provide ideological content for a sacred form of behaviour'. ${ }^{12}$ This is partly due to its secular nature. There is no formal or indoctrinated meaning attached to the big bang theory that you might see in Theogony. Unless a leap is made to call scientific practice 'a sacred form of behaviour' based on the belief that a layperson has in it, or even 'ideological' the big bang does not contain the same context as a myth like Hesiod's Theogony.

12 Honko, 'The Problem of Defining Myth', p. 51. 


\section{Implications and criticisms}

After evaluating the big bang under the criteria above, the big bang may be called a myth. This applies specifically to those who do not have an advanced understanding of the evidence behind the theory. The big bang's mythic qualities, therefore, may not be as strong as that of Theogony - and calling it a myth certainly wouldn't resonate in everyday usage. This has implications on the theoretical understanding of myth, and what scholars can use as appropriate analytical tools to study myth.

Taking into account 'modern myths' or 'modern aetiologies' may open up the study of myth. Hawes states that 'specific attitude towards mythology will create its own particular conception of the nature of myth which will, in turn, determine which stories should be considered "mythic". ${ }^{13}$ These attitudes towards myth may come from a particular scholar's background and what they study. For example, Malinowski was an anthropologist, and theorised myth through its cultural function, leading to his idea that myth is 'not symbolic but a direct expression of its subject matter'. ${ }^{14}$ Furthering this idea that defining myth is 'circular', this essay must have implicit biases by considering the big bang 'mythic'. To make these clear, this essay emphasises the importance of the epistemic system in the context of the form of the myth as its most defining characteristic. What makes the big bang a myth is the layperson's belief in it, with its associated narrative, content, and imagery. By loosening the definition of myth in this way, my own argument in this essay is strengthened, whereas if I used other definitions, my thesis may be invalidated. However, by shifting the importance of myth to that of its epistemic quality, a much wider range of narrative or stories may be considered myth and studied under that umbrella.

Demythologisation and ideology are important concepts in this discussion. Demythologisation is a term that describes a phenomenon in which what may be considered a myth is classified as something other. ${ }^{15}$ The best example to show this is the Christian Resurrection. Whilst Christian believers might be insulted if you were to call the Resurrection a myth, the story itself holds true to all of the previous criteria of myth. This phenomenon can occur under

13 Greta Hawes. 2014. Rationalizing Myth in Antiquity. Oxford, New York: Oxford University Press, p. 73.

14 Malinowski, 'The Role of Myth in Life', p.194.

15 Honko, 'The Problem of Defining Myth', p. 42. 
three different methods: terminological; total and compensatory; and partial and interpretive. The most important of these that pertains to this discussion is terminological demythologisation. This is when the 'word myth is avoided but the account, the story itself, is retained' ${ }^{16}$ This act is certainly ideological in its nature - as by denying a narrative or account the title of 'myth', one is making a judgement on the nature and content of the account itself. Lincoln explores this idea, and states "myth" asserts certain aspects of validity and authority compared to other forms of discourse. ${ }^{17}$

The big bang often undergoes demythologisation, however, through the analysis given above it can be seen that it is valid to explore the account through a mythological perspective. The big bang - as a current and 'scientific' cosmogony - is immune to the term 'myth'. The emphasis of this essay's thesis, therefore, is on how the definition of myth, at least in academic circles, should be opened up to account for these ideological influences. If one can understand myth not through an ideological perspective or as a label of something invalid or untrue, one may explore a greater range of stories and accounts with the same or similar qualities. A myth is not just a 'traditional oral tale', but has an inherent epistemic belief system attached to it that makes up a part of its function. It is therefore not analytically useful to close off options for mythological study based on vogue ideological trends.

\section{Conclusions}

This essay and its research have a few obvious weaknesses. The survey conducted was not representative of the larger community of people in Australia, and could have been sampled to account for this. This may have been achieved through questions that delineated a respondent's level of education, and their age. Additionally, the topic of defining myth is extremely large and has already been explored by experienced academics to a greater and deeper extent than the author has the knowledge to do. However, this essay has aimed to discuss some of the issues when defining myth by comparing a modern aetiology and an ancient one. Through this, it has been concluded that ideological aspects

16 Ibid.

17 Lincoln, Theorizing Myth: Narrative, Ideology, and Scholarship, p. 15. 
that influence the definition of myth are limiting to analysis and distract from the essence of what myth is and that the definition should be more inclusive so as to account for a wider range of stories and narratives.

\section{References}

Dundes, Alan (editor). 1984. Sacred Narrative. Los Angeles: University of California Press.

Hawes, Greta. 2014. Rationalizing Myth in Antiquity. Oxford, New York: Oxford University Press.

Hesiod. 2006. Theogony. Works and Days. Testimonia. Vol. 57, 503. Edited and translated by Glenn W. Most. Cambridge, Mass: Harvard University Press.

Lincoln, B. 1999. Theorizing Myth: Narrative, Ideology, and Scholarship. Chicago: University of Chicago Press.

Maurizio, L. 2015. Classical Mythology in Context. USA: Oxford University Press.

Theoi Project. 'K1.1 Zeus.' www.theoi.com/Gallery/K1.1.html.

Theoi Project. 'K6.2 Artemis.' www.theoi.com/Gallery/K6.2.html. 
This text is taken from Merici, Volume 2, 2016, edited by Matthew Rogers, published 2017 by ANU eView, The Australian National University,

Canberra, Australia. 